\title{
AMENDMENTS
}

\section{Publisher Correction: Firing up ambition}

Correction to: Nature Climate Change https://doi.org/10.1038/s41558-019-0680-9, published online 2 January 2020.

In the version of this Editorial originally published, the text '25th Congress of Parties (COP25)' was incorrect; it should have read '25th Conference of the Parties (COP25) to the UN Framework Convention on Climate Change'. The text 'The Convention on Biological Diversity will meet' was also incorrect; it should have read 'The parties to the Convention on Biological Diversity will meet'. This has now been corrected.

Published online: 27 January 2020

https://doi.org/10.1038/s41558-020-0708-1

○) Springer Nature Limited 2020

\section{Publisher Correction: Reduced European aerosol emissions suppress winter extremes over northern Eurasia}

Yuan Wang (D), Tianhao Le (D), Gang Chen (D), Yuk L. Yung (D), Hui Su (D), John H. Seinfeld (D) and Jonathan H. Jiang (D)

Correction to: Nature Climate Change https://doi.org/10.1038/s41558-020-0693-4, published online 3 February 2020.

In the version of this Letter originally published, in Fig. 3 caption, the latitude zone for panels $\mathbf{b}$ and $\mathbf{d}$ was incorrect: " $0-50^{\circ} \mathrm{N}(\mathbf{b}$ and $\mathbf{d})$ " should have read " $20-50^{\circ} \mathrm{N}$ (b and $\left.\mathbf{d}\right)$ ". This error has now been corrected in the online versions of the Letter.

Published online: 13 May 2020

https://doi.org/10.1038/s41558-020-0800-6

(c) The Author(s), under exclusive licence to Springer Nature Limited 2020 